\title{
DETERMINANTS OF POLYTECHNIC EDUCATION IN PRE-SCHOOLS
}

Jarmila HONZÍKOVÁ, University of West Bohemia in Pilsen, Czech Republic

Přijato: 24. 3. 2016 / Akceptováno: 15. 5.2016

Typ článku: Teoretická studie

DOI: $10.5507 /$ jtie.2016.012

Abstract: The study deals with polytechnic education and innovation of approaches to technical education in pre-schools. Pre-school education is characterised by certain specificities which are determined by developmental, cognitive, social and emotional needs of children of this age. The fulfilment of these needs is also in focus of polytechnic education at pre-schools. This theoretical study clarifies the terms working aktivity, working education and polytechnic education, and specifies the objectives of these educational fields. It also shows how to approach the achievement of these objectives in a new and creative way.

Key words: pre-school, polytechnic education.

\section{DETERMINANTY POLYTECHNICKÉ VÝCHOVY V PŘEDŠKOLNÍM ZAŘÍZENÍ}

Resumé: Studie se zabývá polytechnickou výchovou a inovací prístupi̊ $k$ technickému vzdèláváni v mateřské škole.

Předškolni vzděláváni je charakterizováno určitými specifikami, které jsou určovány vývojovými, kognitivními, sociálními a emocionálními potřebami ditéte tohoto věku. Na plněni těchto potřeb je zaměrena i polytechnická výchova $v$ materské škole.

Předložená teoretická studie objasňuje pojmy pracovní činnosti, pracovní výchova, polytechnická výchova a upresn̆uje cíle $v$ těchto výchovných oblastech. Zároven̆ ukazuje, jak tvořivě a nově přistupovat k plněni těchto cílü.

Klíčová slova: mateřská škola, polytechnická výchova.

*Autor pro korespondenci: jhonziko@kmt.zcu.cz 


\section{1 Úvod do problematiky}

Předškolní vzdělávání je založeno na integrovaném prístupu k osobnosti dítěte a v mnohém se liší od vzdělávání žáků základních škol. Je to vzdělávání, které by se mělo přizpůsobit vývojovým, kognitivním, sociálním i emotivním potřebám dětí této věkové skupiny. Pokud vzdělávání probíhá na základě integrovaných bloků, ve kterých se prolínají jednotlivé vzdělávací oblasti a zároveň respektuje vývojová specifika, stává se pro dítě přirozené, smysluplné a užitečné. Integrovaný př́stup $\mathrm{k}$ osobnosti dítěte je základem polytechnické výchovy v předškolním zařízení, která by měla respektovat nejen vývojová stadia, ale zároveň i jednotlivé vzdělávací oblasti.

V roce 2015 vydalo MŠMT výzvu na podávání projektů zaměřených na polytechnické vzdělávání v mateřské škole - Vyhlášení dotačního programu Podpora polytechnické výchovy v mateřských školách. FPE ZČU, jako spousta dalších fakult a mateřských škol v České republice, vstoupila do této výzvy s projektem Obsah, metody a formy polytechnické výchovy v mateřských školách. Díky těmto projektům se začal pojem polytechnická výchova používat i pro specifické vzdělávání v mateřské škole. Použití tohoto pojmu bylo a je velmi rozdílné a nejednotné. Analýza závěrečných zpráv k projektům ukázala, že se pojem polytechnická výchova vyskytuje jako synonymum pro pracovní činnosti, práce s materiálem, práce s nástroji, apod. Jde o velmi subjektivní vnímání tohoto pojmu, a nejen tohoto - ukázalo se, že učitelům v mateřských školách nejsou jasné ani další základní pojmy jako je praktická činnost, pracovní výchova, konstrukční činnosti apod. Ke stejným závěrům ve svém výzkumu došla i Roučová (2015), která uvádí, že „subjektivní vnímání mnoha především techničtejǰsích pojmů mělo u respondentů nevyhovující, zkreslenou, nerealistickou podobu.“

Snahou této teoretické studie je upřesnit nejčastěji používané pojmy a pokusit se je uvést $\mathrm{v}$ určité hierarchii.

\section{Použité metody}

Při zpracování studie byly použity především teoretické metody, zejména studium výzkumných zpráv, kurikulárních dokumentů, strategických vládních dokumentů a dostupné domácí i zahraniční literatury. Při studiu jsme se zaměřili na využívání pojmu polytechnická výchova a na obsah polytechnické výchovy v mateřské škole. Pro práci s terminologií byla použita publikace Terminológia v technickej výchove (Stoffa, 2000).

\section{Polytechnická výchova v historickém kontextu}

Veřejnosti je spíše znám pojem polytechnické vzdělávání, který se použivá v oblasti středního a vyššího vzdělávání. Pedagogický slovník (Mareš, Průcha, Walterová, 2013) definuje polytechnické vzdělávání jako vzdělávání poskytující vědomosti o vědeckých principech a odvětvích výroby, znalosti z technických oborů a všeobecně technické dovednosti.

Ovšem ani pojem „polytechnická výchova“ není nový a ani neznámý. Snad poprvé se tímto pojmem můžeme setkat v učení Karla Marxe (Marx, 1913), jehož pedagogická činnost byla ovlivněna názory Roberta Owena (Mojžíšek, 1962). V 18. a počátkem 19. století dochází $\mathrm{k}$ rychlému rozvoji průmyslové výroby a tím i k problémům, mezi něž lze zařadit využívání dětí jako pracovníků v továrnách. Tento problém se ponejvíce vyskytoval v oblastech, kde 
strojová výroba nahradila manufakturní způsob výroby a to byla tehdejší Anglie. R. Owen (Mojžíšek, 1962) se postavil proti dětské práci a žádal celonárodní vědeckou, pracovní, intelektuální a morální výchovu. Dokonce požádal zákonodárce, aby dětská práce byla omezena alespoň na hranici 12 let. Zároveň propagoval vznik dvou druhů škol, které by fungovaly při továrnách. Jednalo se o školy pro děti od 2 do 6 let, které navštěvovaly především děti pracujících rodičủ, a školy pro děti od 6 do 12 let, které by navštěvovaly děti pracující $\mathrm{v}$ továrně. Tyto školy měly děti naučit nejen číst a psát, ale i dalším mnoha praktickým činnostem a zároveň posílit jejich vztah $\mathrm{k}$ práci. $\mathrm{V}$ polovině 19 . století se objevilo učení Karla Marxe, které vycházelo právě z faktu vykořist'ování dětí prací. Marx ovšem hovořil za dělnickou třídu a tak celé jeho učení bylo postaveno na práci jako základu životní existence - na jedné straně odmítal dětskou práci, na straně druhé však považoval práci za důležitý výchovný prostředek. Výchova v Marxově pojetí obsahovala tři části:

1. Duševní výchovu.

2. Tělesnou výchovu a vojenský výcvik.

3. Polytechnickou výchovu.

Oblast duševní výchovy zahrnovala předměty kognitivního základu, tělesná výchova a vojenský výcvik přispívaly k tělesné zdatnosti dětí. Polytechnická výchova měla zajistit, aby se žáci a mládež seznámili s hlavními zásadami všech výrobních procesů a zároveň se naučili zacházet $\mathrm{s}$ nejjednoduššími nástroji ze všech výrobních odvětví. Proto měla polytechnická výchova dvě složky - teoretickou a praktickou. K postavení práce ve výchovném systému se vyjádřil i další ruský pedagog Konstantin Dmitrijevič Ušinskij (Honzíková, Bajtoš, 2004). Svoje zkušenosti čerpal v západních zemích a chtěl, aby výchova probíhala $\mathrm{v}$ jakési harmonii, kterou by tvořila národnost, jazyk, práce a věda. Práci prrikládal Ušinskij velmi prazvláštní význam - považoval ji za trest, který vyplývá z prvotního hříchu člověka, ale zároveň ji pokládal za nevyhnutelnou podmínku tělesného, mravního a rozumového zdokonalování člověka, za projev svobody, štěstí a smyslu života. Ušinskij měl tímto na mysli, že každý člověk je hříšník a tudíž musí každý pracovat. Po druhé světové válce se věnovala velká pozornost polytechnické výchově obzvláště v tehdejším Sovětském Svazu. Např. N. K. Gončarov (1946) zdůrazňuje, že polytechnizace se nesmí přizpůsobovat pouze technice, ale $\mathrm{v}$ potaz je nutné brát i základy dalších věd. To, které vědy jsou pro polytechnickou výchovu ty nejdůležitější, je určeno ekonomickou situací společnosti a kulturní vyspělostí daného národa.

\section{Polytechnická výchova v současnosti}

V současné době se v našem i zahraničním školství objevuje pojem polytechnická výchova spíše v souvislosti se stř̌edním a vyšším vzděláváním. Ovšem někteří zahraniční autoři poukazují na důležitost polytechnické výchovy již od útlého věku právě ve spojení s ekonomickým rozvojem (Chibuzor, 2014). Chibuzor poukazuje na důležitost seznamování dětí s výrobním odvětvím, které je základem ekonomického růstu. Nejen ekonomická gramotnost, ale také nový př́stup k environmentální výchově (zemědělství, zdraví, výživa) je důležitý obzvláště v zemích Afriky (Clark, 2015; Mwangi, Serem, 2013).

Vyspělejší kultury, jako např. USA, se spíše orientují na využivání nových technologií v předškolním zařízení. Wardle (2010) se zabýval vhodností počítačů pro děti od tří let. Přínos 
využívání počítačů vidí Wardle nejen v možnosti vzdělávání dětí se zvláštními potřebami, ale i v možnosti vychovávat děti rozmanitě, citlivě a individuálně, nebot' podle něho výrobci softwarů přihližejí $\mathrm{k}$ vývojovým zvláštnostem dětí.

Jak tedy porozumět pojmu polytechnická výchova a jaké je její postavení ve vzdělávacím systému mateřské školy v České republice? V následujícím textu se pokusíme objasnit pojem polytechnická výchova v souvislostech, ukázat postavení polytechnické výchovy ve vzdělávacím systému mateřské školy. Domníváme se, že objasnění těchto pojmů mělo předcházet projektové výzvě MŠMT.

\section{Postavení polytechnického výchovy $\mathrm{v}$ předškolním vzdělávání a určování cílů}

Nejprve se pokusíme definovat nejčastěji používané pojmy a ukázat jejich hierarchii ve vzdělávání v mateřské škole.

- Pracovní činnosti - jedná se pouze konkrétní práci s materiály, jako je např̀. stř́hání, nalepování, modelování.

Cíle pracovních činností:

○ získat manuální dovednosti,

○ umět aplikovat získané dovednosti na různých námětech.

- Pracovní výchova - je již širší pojem, který zahrnuje kromě pracovních činností i získávání základních dovedností a návyků při práci s materiály, poznávání materiálů, technologickou kázeň při práci, bezpečnost při práci, plánování, výchovu ke kladnému vztahu k práci.

Cíle pracovní výchovy:

○ získat základní a praktické pracovní návyky při práci s různými materiály,

○ poznávat vybrané materiály,

- osvojovat si zásady bezpečnosti a ochrany zdraví při práci, hygieny práce, základy organizace a plánování práce,

- vytvářet pozitivní vztah $\mathrm{k}$ práci.

- Technická výchova - má za cíl seznámit děti v mateřské škole s fungováním a používáním techniky kolem nás.

Cíl technické výchovy:

- vést děti ke správnému postoji $\mathrm{k}$ technice.

- Polytechnická výchova - je pojem, který lze považovat za nadřazený výše uvedeným, nebot' obsahuje nejen pracovní činnosti a pracovní výchovu, ale zároveň i poznávání výrobních technologií jednotlivých materiálů, orientaci v různých oborech lidské činnosti, tvorbu životního prostředí, poznávání a používání multimédií a nových technologií. Proniká všemi vzdělávacími oblastmi, poukazuje na to, že vědeckým základem techniky je nejen mechanika, ale i matematika, fyzika a prírodověda.

Polytechnická výchova usiluje ještě o vyšší cíle než pracovní výchova, nebot' se snaží, aby děti získaly nejen určité manuální dovednosti při práci s materiály, ale zároveň uměly

○ poznat vybrané materiály a jejich užité vlastnosti, naučit se volit a používat pro práci vhodné nástroje, nářadí a pomůcky, osvojit si jednoduché pracovní postupy potřebné pro běžný život, 
○ poznat význam vědních oborů,

○ osvojit si základy organizace, plánování práce a technologické kázně,

- vytvářet si aktivní vztah $\mathrm{k}$ ochraně a tvorbě životního prostředí,

○ získat orientaci v různých oborech lidské činnosti, formách fyzické a duševní práce,

○ vytvářet si správný postoj $\mathrm{k}$ technice a její využívání v běžném životě,

- pro poznávání světa využívat konstrukční činnosti,

○ poznávat a učit se používat nová multimédia. (RVP PV, 2006).

Velmi výstižně a přitom jednou větou popisuje význam polytechnického vzdělávání Provázková Stolinská (2015, s. 5):

„Polytechnické vzdělávání je v současnosti vnímáno jako velmi efektivní prostředek pro komplexní rozvoj dítěte."

\section{Integrace polytechnické výchovy do Rámcově vzdělávacího programu pro předškolní vzdělávání}

Jednotlivé oblasti vzdělávání v předškolním zařízení jsou rozlišeny na základě vztahů, které si dítě vytváři $\mathrm{k}$ sobě samému, $\mathrm{k}$ druhým lidem i k okolnímu světu, tzn. na základě prrirozených interakcí, do kterých dítě $\mathrm{v}$ rámci vztahů vstupuje, v nichž žije, rozvíjí se a vyrůstá. Těchto interakčních oblastí je celkem pět: biologická, psychologická, interpersonální, sociálně kulturní a environmentální. Od nich jsou pak odvozeny i jednotlivé oblasti předškolního vzdělávání. V těchto oblastech je integrována polytechnická výchova svými specifickými činnostmi:

○ Dítě a jeho tělo (oblast biologická) - zdokonalování jemné a hrubé motoriky při různých manipulačních činnostech, sebeobslužné práce.

- Dítě a jeho psychika (oblast psychologická) - estetické a tvůrčí aktivity, resp. činnosti zajištující radostné prožitky přri tvořivé práci, při řešení problémových úloh.

- Dítě a ten druhý (oblast interpersonální) - rozvoj komunikativních dovedností při společných tvůrčích aktivitách, rozvoj interpersonálních vztahů při různých činnostech.

- Dítě a společnost (oblast sociálně kulturní) - skupinové aktivity, situační hry uvádějící děti do světa lidí, využívání ICT jako komunikačního prostředku.

- Dítě a svět (oblast environmentální) - praktické uživání techniky a hraček, používání ICT jako informačního prostředku, poznávání nástrojů a nářadí a jejich funkce, seznamování s prírodninami a lidskými produkty, péče o životní prostředí (RVP PV, 2006).

\section{Determinanty polytechnické výchovy}

Polytechnická výchova, jak bylo výše uvedeno, nachází svoje místo při práci s různým materiálem, při konstrukčních činnostech, při sebeobslužných činnostech, v úklidových, pěstitelských a chovatelských pracích, při rozvoji komunikačních dovedností, při rozvoji tvořivosti, při začleňování dítěte do kolektivu. 
Za determinanty polytechnické výchovy lze proto považovat ty výchovně - vzdělávací oblasti, které vedou k celkovému rozvoji dítěte - manuální činnosti, pracovní výchovu, technickou a environmentální výchovu.

Četné výzkumy (Dostál, 2015; Honzíková, 2015; Roučová, 2015; Provázková Stolinská, 2015) ukázaly důležitost manuálních dovedností nejen pro rozvoj tvořivých schopností, ale pro komplexní rozvoj dítěte.

Pracovni výchova vede děti nejen získávání základních dovedností a návyků při práci s materiály, ale zároveň i k poznávání materiálů, učí je technologické kázni při práci, dodržování bezpečnost při práci, učí je plánovat si práci, vychovává ke kladnému vztahu k práci.

Technická výchova připravuje děti na život $\mathrm{v}$ technické společnosti a vede je ke kladnému vztahu $\mathrm{k}$ technice a $\mathrm{k}$ jejímu účelnému využívání.

Environmentální výchova pomáhá dětem poznávat svět ve všech souvislostech, umožňuje jim vstup do dalších vědních disciplín, učí je poznávat př́rodovědné, matematické, fyzikální a prírodovědné zákonitosti světa, ve kterém žijí.

Všechny výše uvedené determinanty polytechnické výchovy jsou vzájemně propojeny, navzájem se ovlivňují a vytvářejí celek, který je ovšem neoddělitelný od životní skutečnosti (RVP PV, 2006).

\section{Diskuse a závěr}

V dnešní technické společnosti je více než žádoucí rozvíjet polytechnické myšlení u dětí již od útlého věku. Polytechnická výchova není jen, jak již bylo uvedeno, pracovní výchova či pracovní činnosti, ale je to poněkud širší výchova, která zahrnuje nejen oblast techniky kolem nás, ale i badatelsky orientovaný př́stup k poznávání materiálů a okolního světa, tvůrčí technické aktivity, konstrukční činnosti při práci se stavebnicí a mnoho dalších aktivit, které vedou děti ke správnému vztahu $\mathrm{k}$ dnešní technické společnosti. Všechny tyto činnosti smysluplně obohacují denní program dítěte $\mathrm{v}$ průběhu docházky do předškolního zařízení a připravují ho tak pozvolna na nástup do základní školy, a nejen to, tyto činnosti by měly vzbudit u dětí budoucí zájem o technické obory. Cíl polytechnické výchovy je nejen získávat manuální dovednosti a poznávat výrobní odvětví, jako to bylo v období K. Marxe (1913), ale dostává hlubší rozměr právě ve spojení s moderními informačními a komunikačními technologiemi.

Ve výše zmíněném dotačním programu Podpora polytechnické výchovy v mateřských školách se ovšem pojem polytechnické vzdělávání vyskytuje pouze v názvu, v samotné výzvě se již argumentuje s pojmem technické vzdělávání:

a) vybaveni škol stavebnicemi na podporu rozvoje pracovnich schopností a dovedností,

b) vybaveni nebo obnova vybaveni tř́d mateřských škol nebo technických dílen základnich škol učebnimi pomůckami pro technické vzděláváni (zejm. ručním náradím, akumulátorovým elektrickým náradím, spotřebním materiálem),

c) zajištěni metodických materiálio a dalšiho vzděláváni pedagogických pracovníků př́mo souvisejicí s použiváním vybavení škol pořizeného v rámci projektu, včetně motivace žákio k technickému vzdělávání,

d) vzděláváni dětí a žáků $v$ science center (tj. středisko neformálniho vzdělávání, které se primárně zaměruje na cílenou popularizaci védy a techniky; nejedná se přitom o klasickou 
vzdèlávací instituci, důraz je kladen zejména na interaktivitu a učení formou her a samostatného objevování védy a techniky prostřednictvím osobni zkušenosti), a to formou úhrady vstupného do science center. (http://www.msmt.cz/vzdelavani/zakladnivzdelavani/vyhlaseni-dotacniho-programu-podpora-polytechnicke-vychovy)

Řešitelé projektů přistupovali k plnění výzvy velmi flexibilně. V souvislosti s plněním projektů uvádíme výňatky $\mathrm{z}$ webových stránek mateřských škol, které se týkaly polytechnické výchovy:

„Polytechnická výchova $(P V)$ rozvíji znalosti o technickém prostředí a pomáhá u dětí vytváŕet a fixovat správné pracovní návyky. Posiluje zájem o technické obory a podporuje touhu tvořit. Patř́ sem i použivání jednoduchých nástrojü, netradičních materiálů a techniky jejich zpracování." (http://www.mskamenice.cz/projekty)

„Posledni dobou je slyšet v médiích o novince ve vzděláváni děti v předškolním věku a to o zavádèní polytechnické výchovy. Domnívám se, že vztah $k$ vědě a technice i pracovní návyky

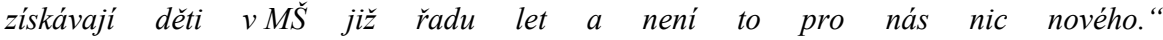
(http://www.zsstramberk.cz/polytechnicka-vychova-v-ms-bariny)

„Celý tento školní rok klademe v naši MŠ větši dưraz na polytechnické vzděláváni dètí. Jde o celkovou snahu školství probudit v dètech zájem o technické a přirodovědné obory. " (http://www.skolkaformana.estranky.cz/clanky/aktivity-ms/polytechnicke-vzdelavani/)

„Polytechnická výchova znamená naučit dèti správným pracovním návykům, použivat jednoduché nástroje, seznámit je s různými materiály a také s postupy a technikami jejich zpracováni. “ (http://www.skolaarcha.org/?p=5083)

„Děti se ve školce uči orientovat v technickém světě, porozumět mu a poznávaji vše okolo aktivně. " (http://www.mszdar.cz/polytechnicka-vychova-v-materske-skole/)

„Pojem polytechnická výchova v MŠ zahrnuje široké téma pro různé oblasti a činnosti vzdèláváni předškolních dètí. Jedná se napríklad o rozvoj matematických dovedností, hry $s$ materiálem a techniky zpracováni materiálio, seznamováni s řemesly, použiváni jednoduchých pracovnich nástrojü, konstruktivni hry se stavebnicemi a technickými kreativnimi hračkami. Děti se také hravou formou seznamuji s rủznými poznatky v oblasti přirodnich věd pomoci běžných činností, jevĩ a předmětů, které nás obklopuji. Polytechnická výchova poskytuje dětem možnost seberealizace, pocitu, že něco zvládly a dokázaly." (http://ms-lucni.webnode.cz/news/polytechnicka-vychova-v-praxi/)

Z uvedeného vyplývá, že plnění projektu bylo orientováno hlavně na zvýšení zájmu o technické obory, na různé činnostní aktivity, na vytváření pozitivního vztahu $\mathrm{k}$ technice a jiným vědám, jakož i na materiální vybavení předškolních zařízení. Cíle projektu lze můžeme považovat za splněné.

V závěru studie se pokusíme uvést některá doporučení pro zkvalitnění obsahu polytechnické výchovy v mateřských školách:

sjednotit základní terminologii z oblasti polytechnické výchovy - jsou to učitelé, od kterých přijímají děti nové názvosloví,

stanovit cíle polytechnické výchovy v návaznosti na ostatní vědy - uvědomit si důležitost př́rodovědného, matematického a dalšího vzdělávání $\mathrm{v}$ kontextu polytechnické výchovy, 
- $\quad$ v rámci polytechnické výchovy stanovit pro děti přijatelné cíle - takové, které budou určovat nejen úroveň manuálních dovedností, ale i míru ovládání a využívání nových informačních a komunikačních technologií,

- volit takové vyučovací metody a formy práce, které budou děti motivovat a podporovat jejich touhu po poznávání.

Př́stup $\mathrm{k}$ pojetí polytechnické výchovy by se měl změnit již při přípravě budoucích učitelů.

\section{Literatura}

Dostál, J. (2015). Badatelsky orientovaná výuka. Pojetí, podstata, význam a přínosy. Olomouc: UPOL.

Clark, N. (2015). Education in Kenya. World Education News \& Reviews. June, 2015.

Gončarov, N. K. (1946). Вопросы политехнический и общего образования. Советская педагогика. Moskva. C.. 4 - 5 .

Honzíková, J. \& Bajtoš, J. (2004). Didaktika pracovní výchovy na 1. stupni ZŠ. Plzeň: Západočeská univerzita, Fakulta pedagogická.

Honzíková, J. (2013). The Combined Form of Study of the Pedagogy for Nursery Schools and the Elektronic Support. In International Journal of Inovation and Research in Educational Sciences, Volume 1, Issue 4.

Honzíková, J. (2014). Pracovní činnosti v předškolní výchově. In: Čábalová, D. (Ed.) Pregraduální vzděláváni učitelů mateřských škol jako dialog mezi teorii a praxi. [online]. Plzeň: $\quad$ FPE ZU V Plzni. Dostupné http://www.zcu.cz/pracoviste/vyd/online/Pregradualni_vzdelavani_ucitelu_MS.pdf

Honzíková, J. (2015). Pracovní výchova jako součást polytechnické výchovy v mateřské škole. In: Slowík, J. Obsah, metody a formy polytechnické výchovy v mateřských školách. Plzeň . ZČU.

Honzíková, J. (2015). Psychomotorické dovednosti jako součást polytechnické výchovy. In: Trends in Education. Information Technologies and Technical Education. 1/2015, vol. 8. s. $132-136$.

Chibuzor, A. N. (2014). Enhancing Creativity in Entrepreneurship trough Home Economies Education in Nigeria. In: American International Journal of Contemporary Research. Vol. 4., No. 6. pp. 104 - 107. Center for Promoting Ideas, USA.

Kahuda, F. (1951). Za rozvíjení polytechnického vzdělávání. In: Teorie a dějiny pedagogiky. Praha.

Kolektiv autorů. (2006). Rámcový vzdělávací program pro předškolní vzdělávání. Praha: Výzkumný ústav pedagogický.

Kolektiv autorů. (1978). Program výchovné práce pro jesle a mateřské školy. Praha: SPN.

Marx, K. (1913). Kapitál. Praha: Svazek první.

Mareš, J.,Průcha, J. \&Walterová, E. (2013). Pedagogický slovník. Praha: Portál.

Mojžíšek, L. (1962). Kotázce pojetí fyzické práce žáků v předsocialistické a socialistické škole. Sborník prací filosofické fakulty Brněnské university.

Mwangi, M. P.\& Serem, T.D.K. (2013). Basic education from early childhood: Impacts of free primary education and subsidized secondary education on public ECDE centers in 
Nyahururu District, Kenya. In: International Journal of Educational Administration and Policy Studies. Vol.5(6), pp. 110-115.

Parkinson, E. (2001). Teacher Knowledge and Understanding of Design and Technology for Children in the 3-11 Age Group: A Study Focusing on Aspects of Structures. In Journal of Technology Education. Vol. 13, N. 1. [cit. 2015-06-12]

MŠMT. (2015). Vyhlášení dotačního programu. Podpora polytechnické výchovy $v$ mateřských školách. Dostupné na: http://www.msmt.cz/vzdelavani/zakladnivzdelavani/vyhlaseni-dotacniho-programu-podpora-polytechnicke-vychovy-v

Provázková Stolinská, D. (Eds.). (2015). Polytechnické vzdělávání v prostředi mateřské školy. Olomouc. UPOL.

Roučová, E. (2015). Jak vnímají vybrané technické a didaktické pojmy učitelky mateřských škol. In: Journal of technology and information education. Vol. 7. N. 2.

Svobodová a kol. (2010) Vzdèlávání v mateřské škole. Praha: Portál.

Stoffa, J. (2000). Terminológia v technickej výchove. Olomouc: UPOL.

Wardle, F. (2008). The Role of Technology in Early Chilhood Programs. In: The Professional Resource for Teachers and Parents. Dostupné http://www.earlychildhoodnews.com/earlychildhood/article_view.aspx?ArticleID=302

Webové stránky mateřských škol (Kamenice, Štramberk, Ostrava, Benešov, Žd'ár nad Sázavou, Semily):

http://www.mskamenice.cz/projekty

http://www.zsstramberk.cz/polytechnicka-vychova-v-ms-bariny

http://www.skolkaformana.estranky.cz/clanky/aktivity-ms/polytechnicke-vzdelavani http://www.skolaarcha.org/?p=5083

http://www.mszdar.cz/polytechnicka-vychova-v-materske-skole/

http://ms-lucni.webnode.cz/news/polytechnicka-vychova-v-praxi/ 